\title{
Moving Beyond a Sign of Judgment: Primary School Teachers' Perception and Practice of Feedback
}

Askalemariam A. Dessie

$\mathrm{PhD}$, Department of Psychology, Institute of Education and Behavioral Sciences, Debre Markos University, Ethiopia, askaleadaти @ gmail.com

Abatihun A. Sewagegn

$\mathrm{PhD}$, corresponding author, Department of Educational Psychology, Faculty of Education, University of Johannesburg, South Africa, abatihuns@uj.ac.za \& abatihunalehegn@gmail.com

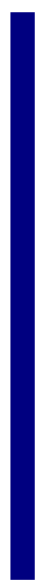

\begin{abstract}
Effective feedback plays a great role in the teaching-learning process and learners' performance. This becomes possible when teachers have positive perception regarding feedback and practice it very well. Therefore, the purpose of the study was to assess primary schools teachers' perception and practice of feedback. To achieve this purpose, concurrent parallel mixed methods design was used and 61 teachers were participated in the study. Questionnaire, semi-structured interview and document review were used to collect quantitative and qualitative data. Quantitative and qualitative data analysis techniques were used. The result showed that the majority of teacher's perception and practice of feedback to improve students learning was good (they provide immediate feedback). But, there are gaps in using feedback as learning purpose rather than for judgment. Thus, even if teachers have good perception and practice, the use of feedback for learning purpose is overlooked. Therefore, training teachers regarding the use and provision of effective feedback is the main task of the schools and education office experts at the regional and national level.
\end{abstract}

Keywords: assessment, feedback, judgment, perception, practice, teachers, teaching

\section{INTRODUCTION}

Feedback is one of the fundamental tasks of teachers to advance the students' learning. It is clear that when feedback to students is given properly, use of feedback information can help to close the gap between students' current and desired performance (Hattie \& Timperley 2007). Feedback on learner performance has been identified as an essential feature of successful instruction for teachers of all subjects and grade levels (Gan, Nang $\& \mathrm{Mu}, 2018$ ) and it is central to the development of effective learning (Sadler, 2010).

Citation: Dessie, A. A., \& Sewagegn, A. A. (2019). Moving Beyond a Sign of Judgment: Primary School Teachers' Perception and Practice of Feedback. International Journal of Instruction, 12(2), 51 66. https://doi.org/10.29333/iji.2019.1224a 
Research evidences indicated that feedback can have a very powerful effect on the teaching-learning activity (Hattie \& Timperley, 2007) and it is an essential part of formative assessment both to assess learners current achievement and to indicate next steps in their learning (Black, Harrison, Lee, Marshall and Wiliam, 2003, Irons, 2008).

The feedback that the teachers are providing should be effective to bring improvement in students' learning (Irons, 2008; Sadler, 2010). Effective feedback initiates thinking, helps learners to know how to do to improve their learning, allows learners to see the quality of their work against that of the teacher or peer and empower learners to become self-regulated learners (Fautley and Savage, 2008; Moss and Brookhart, 2009; Sadler, 2010). If feedback is effective, it should be understandable by students, 'close the gap' on their understanding, be of appropriate quality, timely, and provide an opportunity for dialogue (Irons, 2008: 44, 45).

The feedback delivery to be effective, from the beginning the teacher has to have positive perception and the skill. But, there are misconceptions about feedback from the side of teachers and these are related to their perception. In relation to this, Moss and Brokhart (2009) indicated that some teachers view returning graded work and detailed correction as effective feedback. In addition to this, teachers perceived that writing feedback is too time-consuming and they believed that students do not give emphasis for feedback comments because they are only interested in the result (Spiller, 2014).

Usually, teachers' feedback consists of right and wrong answers and comments such as "Good job.", "keep it up.", "it is a good trial.", "you need to study hard." to register their approval or disapproval of student performance (Shepard, 2000). But such evaluative or judgmental feedbacks have limited value to improve students learning and have negative effects on students' desire to learn (Spiller, 2014). Moreover, when teacher feedback focused on "praise, rewards, and punishment" it has a low impact on students learning achievement (Hattie \& Timperley, 2007). By contrast, feedback has the potential to have a meaningful effect on students learning, when the information in the feedback is about a task and how to do it more effectively (Black and Wiliam, 2001).

However, the study conducted by Black, Harrison, Lee, Marshall \& Wiliam (2003) on formative assessment showed the following results on the practice of formative feedback. According to them, teachers rarely give students time in class to read comments that are written on work and probably few, often the comments are not specific, and constructive or does not show next steps in learning, teachers feedback strongly emphasis on comparing students with each other; which demoralizes the less successful learners, teachers mostly give marks, praises... such as excellent, fair, good work etc. that have no value for students learning, and teacher feedback to students often serves managerial and social purposes rather than helping them learn more effectively. Despite recognizing that timely and helpful feedback to students is an important aspect of learning, however, it is not an area that has been widely addressed in the academic research (Weaver, 2006). All of these cases are not an exception in Ethiopia, particularly in the selected area. These were verified through personal experiences and observations. Moreover, as to the knowledge of the researchers, particularly, in the 
study area and topic, no complete research has been done to assess teachers' perception and practice of feedback to improve students' learning at primary schools. Even at the international level, there is less published research about how primary school teachers' perceive and practice feedback incorporating different subjects (Mathematics, Physics, Biology, etc...) at a time. The majority of feedback studies are related to language learning (EFL) particularly writing at higher institutions and in some secondary schools (Lee, 2009; Montgomery \& Baker, 2007). The present study serves to fill this gap by examining the perception and practice of teachers' feedback to improve students' learning in primary schools at Debre Markos, Ethiopia. Thus, the following research questions were raised:

- What perception do teachers have regarding the power of feedback on students' learning?

- How do teachers' provide feedback to their students to improve their learning?

- To what extent teachers' perceptions influence their actual feedback practice?

Hence, the major aim of the study was to assess primary schools teachers' perception and practice of feedback. Thus, findings of this study can contribute new knowledge or dimension to the existing theory and strengthen theories and principles related to constructive feedback. In addition, the expected result may deepen our understanding of the perception and practice of teacher's feedback and inform policymakers, educational experts, teachers, students and other concerned bodies.

\section{REVIEW OF LITERATURE}

\section{Teaching-Learning, Assessment, and Feedback}

The idea of improving students' learning through assessment is not new. It was strongly acknowledged by cognitive constructivist and social constructivist theory of learning (Black and Wiliam, 1998; Assessment Reform Group (ARG) (2002). According to constructivists' views of learning, teaching-learning processes should focus on deep understanding, provide opportunities for in-depth and conceptual development, and enhance student abilities to recognize and use meaningful patterns of information. These new perspectives of learning have directed a rethinking of the nature of assessment in the teaching-learning process. For them, assessment should be integrated with the teaching and learning process to improve students' learning.

Yet the traditional view of learning (behaviorists), accepts that students are passive recipients of information and learning is determined by the environment (ARG, 2002; Harlen, 2006). They viewed assessment as unseen timed tests and exams and students' progress was interpreted by correct and incorrect answers. Therefore, for behavioral learning theorists, assessment and learning are evolved separately from one another.

Whereas, cognitive constructivists believe that learning requires the active engagement of learners and determined by what goes on in learners' minds. If the learners are active, they can construct their own knowledge. The role of teachers and students became changed and formative assessment emerges as an integral part of pedagogic practice. For constructivist, it is necessary to provoke students' mental models through dialogue, 
questioning, open-ended assignments, thinking and concept-mapping to scaffold them to apply concepts and strategies in novel situations (ARG, 2002; Harlen, 2006; Black and Wiliam, 1998).

The sociocultural perspective also focuses on the nature of social interactions and how these interactions influence learning (Bennett and Gitomer, 2009). This perspective grows out of the work of Vygotsky and suggests that teacher needs to create the environment to stimulate learners to think and act in authentic tasks beyond their current level of competence. Tasks need to be collaborative and students must be involved in the generation of problems and solutions (Eleanore, 2012). Due to this fact, paradigm shift comes into the assessment practice (Black and Wiliam, 1998; ARG, 2002). The shift is from using traditional assessment method to using authentic assessment methods to build a student's learning profile, to assess higher level skills, to increase student responsibility in the assessment process.

This new mode of assessment (assessment for learning) comprises four basic strategies to improve students' learning. These strategies are: 1 ) sharing of learning objectives and assessment criteria for students; 2) involving students in peer and self- assessment; 3) providing effective written and oral feedback that helps students to recognize next steps in learning; and 4) creating questioning and dialogue community in the classroom (Black and Wiliam, 1998; ARG, 2002; Harlen, 2006). Thus, the provision of effective or constructive feedback is one of the main elements to improve students' learning through assessment.

In the teaching-learning process, assessment and feedback cannot be separated. Feedback is an important part of classroom assessment that integrates teaching, learning, and assessment (Lee, 2017). It is a key component of the formative assessment process (Brookhart, 2008) and it is the most common feature of successful teaching and learning activity (Hattie \& Timperley, 2007). Feedback is a teacher's response to student work with the intention of broadening learning and it can be written or oral, or it can be a demonstration (Moss \& Brookhart, 2009) and the provision of these three forms depends on the nature and contents of the subject. Teachers can give feedback about many different things (Moss \& Brookhart, 2009), but this study focuses on teacher feedback to students on their academic work who are assessed by different assessment methods (oral questions, group, and individual activities in the classroom, homework, tests, projects, etc...). Therefore, in formative assessment, feedback has to be descriptive and diagnostic in order to help students understand their strengths and weaknesses and to inform and improve students learning (Lee, 2017). Feedback is not limited to formative assessment; there is also feedback for summative assessments (e.g., final exams).

\section{Effective Feedback}

"Use of feedback to integrate teaching, learning, and assessment" is one of the guiding principles for effective feedback (Lee, 2017). Feedback plays a significant role in enabling students' to improve their performance on future assessment tasks and has been identified as a key strategy in learning and teaching (Poulos \& Mahony, 2008). Lee 
(2008) noted that good quality, comprehensive and timely feedback is a key factor in improving students learning. Lee listed important criteria's for effective feedback.

As to Moss and Brookhart (2009), effective feedback enhances students' cognitive processing, increases students' autonomy, fosters resiliency and persistence, and provides students with specific strategies for next steps in their learning. Lee (2017) also added that feedback should be specific, accurate, timely, and targeted. These are the common criteria's or characteristics of effective feedback which are listed in some research output but there are more. Therefore, providing effective feedback in different forms (written, oral or demonstration) is a key aspect of assessment to enable students to learn from the assessment tasks they are given.

\section{The Power of Feedback to Improve Student Learning}

Feedback has a power to bring substantial effect on students learning and achievement and its power is repeatedly pointed out in works of literature about teaching and learning (Hattie \& Timperley, 2007). As to Lee (2008), feedback can be very powerful if it is done well. The power of formative feedback addresses both cognitive and motivational factors. Lee (2008) verified this in the following way:

Good feedback gives students the information they need so they can understand where they are in their learning and what to do next - the cognitive factor. Once they feel they understand what to do and why most students develop a feeling that they have control over their own learning - the motivational factor (p: 2)

In the teaching-learning process, imparting students with various means and checking their understanding of the lesson using assessment is the main activity of the teacher. But, this is not the end task of the teacher and the students; there is feedback. Hattie \& Timperley, (2007) noted that teachers should be aware of and aim to provide feedback relative to three important feedback questions: "where am I going?" (What are the goals?), "how am I going?" (What progress is being made towards the goals?), and "where to next?" (What activities need to be undertaken to make better progress?). When teachers and students answer these three questions properly, the feedback will be powerful and improve the students learning.

\section{Teachers' Perception and Practice of Feedback}

There is limited evidence about the relationship between teacher's perception and their practice of feedback incorporating different subjects (Mathematics, Biology, Chemistry, etc...) at a time in primary schools but more studies are found in language learning (Lee, 2008, 2009; Montgomery \& Baker, 2007). Having positive perception to provide effective feedback to the learners is vital and will have a positive contribution to the students learning. But, there may be a factor such as teachers' lack of competence and negative belief (Gul, Tharani, Lakhani, Rizvi \& Ali, 2016) not to provide feedback (i.e., the practice) very well. For example, Lee (2008) indicated that teachers' feedback practices are influenced by teachers' beliefs and values. Another study by Montgomery and Baker (2007) showed that differences both in the actual feedback and in teachers' 
own conceptions about it were observed in teacher and student perceptions of teacher feedback and they argue that all students are not given the same amount of feedback.

In addition, mismatches between teachers' beliefs and their written feedback practices are examined and presented in Lee (2009) study. Lee examined that teachers seem to prefer selective marking, but end up marking errors comprehensively; their practices included correcting and locating errors for students and responding mainly to weaknesses. Therefore, some studies found out that, generally there is no good fit between how teachers conceptualize feedback and how they actually deliver it (Gul, Tharani, Lakhani, Rizvi \& Ali, 2016) and teachers' practices were not in agreement with their beliefs (Li \& De Luca, 2014). But the assumption is that, if someone has positive perception and belief, he/she practices very well. So, the current study will add some input regarding the relationship between the two (teachers perception and practice of feedback) at primary schools.

\section{METHOD}

\section{Research Design}

The main purpose of the study was to assess teachers' perception and practice of feedback to improve students' learning in primary schools. To address the research questions, mixed method research design was used. From different mixed method designs, convergent parallel design (Creswell, 2012) was used to clearly understand the problem under investigation.

\section{Population, Research Context, and Participants}

The populations of the study were teachers from Debre Markos town government and private second cycle primary schools (grade 5 to 8 ). Two government schools (Biruhi Tesfa and Dibiza) and two private schools (Lingerh and Selam Academy) were randomly selected. Since the number of teachers in the four schools (Biruhi Tesfa, 14; Dibiza, 27; Lingerh, 9 and Selam Academy, 11) was manageable, all of them (61) in the selected schools were included in the study.

Four teachers ( 2 males and 2 females), one from each school were selected for interview using convenience sampling technique. All of them were diploma holders having a teaching experience of eight years and above. Those teachers who participated in the interview were also included in the observation.

\section{Instruments}

A questionnaire, semi-structured interview and document review were used to collect data. These multiple data sources allow for triangulation of data to reduce bias and at the same time to develop a deeper understanding of the issues under study (De Vos, Strydom, Fouche and Delport, 2011; Creswell, 2012). The instruments are developed by the researchers.

Questionnaire: A closed-ended questionnaire was used to gather data about teachers' perception and practice of feedback. The questionnaire contains 13 items about 
teachers' perception of feedback and 14 items about the practice of feedback. The perception items have five options (5-point Likert scale) ranging from 1 (strongly disagree) to 5 (strongly agree) and the practice items have also five options ranging from 1 (never) to 5 (frequently).

Semi-structured interview: It was done with selected participant teachers to get detail information about the actual practice. It allows the researchers to explore various issues in-depth with respondents. The interview primarily focuses on how teachers provide feedback to their students; they perceive the power of feedback in improving students learning and what factors influence to provide feedback properly.

Document review: It was conducted to see the content and form of feedback teachers gave in students' exercise book and assessment tasks to assess whether it is judgmental or constructive.

\section{Data Analysis}

To analyze quantitative data, descriptive statistics (frequency, percentage and mean) were employed to give a general description of teachers' perception and practice of feedback. Moreover, a correlation was used to see the relationship between teacher's perception and practice of feedback. For the purpose of comparing frequencies, it was decided to collapse the original 5-point Likert scale into three categories (agree, neutral and disagree) for perception items and (never, sometimes and often) for practice items to enhance clarity at the descriptive analysis level, specifically for the percentage and mean. According to Babbie (2010) collapsing Likert responses is acceptable when one wants to more clearly see a pattern in the findings and so this is done for the descriptive part, but for the purposes of inferential statistics, the full five-point scale was used. The $\alpha$ (alpha) value for test of significance was set at 0.05 level.

The interview and document review data were analyzed qualitatively using words to triangulate the quantitative data. Before the analysis, the interview data was translated from Amharic into English and transcribed by the researchers.

\section{Reliability and Validity}

The questionnaire was validated and piloted prior to the data collection taking 10 teachers from a school (which is not part of the main study site) to test the reliability of the items and checked using Cronbach alpha. The reliability of the questionnaire subscales were 0.72 and 0.79 for perception and practice items respectively which is acceptable based on Goerge Mallery (2003) standard. To increase the validity of the questionnaires and interview items, peers and selected experts in the area were involved to review the questions.

\section{FINDINGS}

To answer the research questions raised, both quantitative and qualitative data were used. The results of the data which were collected using questionnaire, interview and document review were presented based on the following teams: teachers' perception of the power of feedback and their perceived practices. 


\section{Teachers' Perception of the Power of Feedback}

Thirteen items were used to determine teachers' perception of the power of feedback to improve students' learning. The analyses were made using frequency, percentage and mean as shown in Table1 below.

Table 1

Teachers' perceptions on the power of feedback to improve students' learning

\begin{tabular}{|c|c|c|c|c|c|c|c|c|}
\hline \multirow{3}{*}{ No } & \multirow{3}{*}{ Items } & \multicolumn{6}{|c|}{ Responses } & \multirow{3}{*}{ 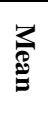 } \\
\hline & & \multicolumn{2}{|c|}{ Disagree } & \multicolumn{2}{|c|}{ Neutral } & \multicolumn{2}{|c|}{ Agree } & \\
\hline & & $f$ & $\%$ & $\mathrm{f}$ & $\%$ & $\mathrm{f}$ & $\%$ & \\
\hline 1 & $\begin{array}{l}\text { Teacher feedback is effective in promoting } \\
\text { students' learning }\end{array}$ & 1 & 1.6 & 0 & 0 & 60 & 98.3 & 4.6 \\
\hline 2 & $\begin{array}{l}\text { In my practice, I use different assessment tools } \\
\text { to continually provide feedback for students' } \\
\text { progress }\end{array}$ & 0 & 0 & 3 & 4.9 & 58 & 95 & 4.5 \\
\hline 3 & $\begin{array}{l}\text { Providing comments is more useful to improve } \\
\text { learning than marks and correct answers }\end{array}$ & 5 & 8.2 & 3 & 4.9 & 51 & 83.6 & 4.3 \\
\hline 4 & $\begin{array}{l}\text { Our feedback practice rarely provides useful } \\
\text { suggestion for future improvement }\end{array}$ & 51 & 83.6 & 3 & 4.9 & 7 & 11.5 & $\begin{array}{l}4.0 \\
8\end{array}$ \\
\hline 5 & $\begin{array}{l}\text { Error analysis in general is effective feedback to } \\
\text { improve students' learning }\end{array}$ & 2 & 3.3 & 4 & 6.4 & 55 & 90.2 & 4.3 \\
\hline 6 & $\begin{array}{l}\text { In my feedback practice, personal improvement } \\
\text { is more valued than competition among students }\end{array}$ & 6 & 9.8 & 14 & 23 & 40 & 65.6 & 3.8 \\
\hline 7 & $\begin{array}{l}\text { Feedback to students serves a social and } \\
\text { managerial functions as opposed to learning } \\
\text { function }\end{array}$ & 33 & 54.2 & 7 & 11.5 & 21 & 35.4 & $\begin{array}{l}3.2 \\
8\end{array}$ \\
\hline 8 & $\begin{array}{l}\text { My students are able to incorporate the feedback } \\
\text { to revise their work in order to meet success } \\
\text { criteria }\end{array}$ & 3 & 4.9 & 3 & 4.9 & 52 & 85.2 & 4.2 \\
\hline 9 & $\begin{array}{l}\text { I view student mistakes as opportunities for their } \\
\text { learning }\end{array}$ & 10 & 16.4 & 7 & 11.5 & 44 & 72.2 & 3.7 \\
\hline 10 & $\begin{array}{l}\text { My students view their mistakes as } \\
\text { opportunities for learning }\end{array}$ & 26 & 42.6 & 16 & 26.2 & 19 & 31.1 & 3.0 \\
\hline 11 & $\begin{array}{l}\text { I believe that peer feedback is important for } \\
\text { students' learning }\end{array}$ & 6 & 9.8 & 6 & 9.8 & 47 & 77 & 4.0 \\
\hline 12 & $\begin{array}{l}\text { Marks provide sufficient feedback to students } \\
\text { about their progress in relation to the learning } \\
\text { targets }\end{array}$ & 16 & 26.3 & 11 & 18 & 34 & 55.7 & 3.4 \\
\hline 13 & $\begin{array}{l}\text { Positive feedback helps low-achieving students } \\
\text { to gain confidence in their ability to learn }\end{array}$ & 7 & 11.5 & 4 & 6.6 & 50 & 81.9 & 4.0 \\
\hline
\end{tabular}

Except for one respondent, 98.4\% (mean $=4.6$ ) of teachers positively and highly perceived the value of teachers' feedback to improve students' learning. Due to this fact, most teachers $(95 \%$, mean $=4.5)$ use different assessment tools to continually provide feedback for their students'. Students' also have the ability to incorporate the feedback to revise their work in order to meet success criteria (perceived by $85.2 \%$ of their teachers). Moreover, $77 \%$ of them believe in the importance of peer feedback for students' learning. As indicated in the table, teachers' feedback practice focuses on personal improvement than competition among students $(65.6 \%)$ because $72.2 \%$ of them view students' mistakes as an opportunity for their learning. 
Even if, $90.2 \%$ and $83.6 \%$ (Mean $=4.3$ ) of teachers agreed on the value of feedback in the form of error analysis and comment to improve students' learning than marks and correct answers respectively, 55.7\% of them indicated that marks provide sufficient feedback to students about their progress in relation to the learning targets.

Most teachers (81.9\%) agreed on the power of positive feedback to build the confidence and self-esteem of low-achieving students in their ability to learn. However, $35.4 \%$ of them believe in the value of feedback for social and managerial functions as opposed to learning function.

In addition to the information obtained using questionnaire, interview was conducted with selected teachers and yielded the following result. One of the interviewees from government primary schools indicated as follow how she perceives classroom feedback:

Classroom feedback is the information that the students provide to their teacher to improve the instructional process and receive from their peers to improve their learning. Our involvement in the feedback process is limited. The majority of the feedback is done by the students themselves. The measure that we took after looking the students work for better improvement is feedback.

Another interviewee from private primary school noted that,

Feedback is the information that we obtain from students whether they understand a certain issue properly or not which is given to them using exercise, oral questions, interview, and written things.

In general, from the interviewees, one can understood that there are gaps regarding the conception of classroom feedback because both of the interviewees isolate their role in the feedback process and gave the task to the students themselves even if the students have their own role.

\section{Teachers' Practice of Feedback to Improve Students' Learning}

In teachers' practice of feedback sub-scale, fourteen items were included. In the subscale, both negative and positive items were included to clearly understand whether teachers' feedback practice is constructive or judgmental. Thus, frequency, percentage and mean were computed to interpret the results for general understanding.

Table 2

Teachers' practice of feedback to improve students' learning

\begin{tabular}{|c|c|c|c|c|c|c|c|c|}
\hline \multirow{3}{*}{ No } & \multirow{3}{*}{ Items } & \multicolumn{6}{|c|}{ Responses } & \multirow{3}{*}{$\frac{3}{3}$} \\
\hline & & \multicolumn{2}{|c|}{ Disagree } & \multicolumn{2}{|c|}{ Neutral } & \multicolumn{2}{|c|}{ Agree } & \\
\hline & & $f$ & $\%$ & $f$ & $\%$ & $\mathrm{f}$ & $\%$ & \\
\hline 1 & $\begin{array}{l}\text { I plan lessons that include feedback as a } \\
\text { fundamental component of the session }\end{array}$ & 4 & 6.5 & 9 & 14.8 & 48 & 78.7 & 4.1 \\
\hline 2 & $\begin{array}{l}\text { My lesson plan includes information on feedback } \\
\text { opportunities }\end{array}$ & 6 & 9.8 & 10 & 16.4 & 44 & 72.1 & 4 \\
\hline 3 & $\begin{array}{l}\text { My lesson plan includes time to provide } \\
\text { feedback to learners }\end{array}$ & 3 & 4.9 & 6 & 9.8 & 52 & 85.3 & 4.2 \\
\hline
\end{tabular}




\begin{tabular}{|c|c|c|c|c|c|c|c|c|}
\hline 4 & $\begin{array}{l}\text { My lesson plan includes opportunities for } \\
\text { learners to reflect on feedback provided }\end{array}$ & 5 & 8.2 & 2 & 3.3 & 54 & 88.5 & 4.2 \\
\hline 5 & $\begin{array}{l}\text { I provide adequate time and structure for } \\
\text { reflection on different tasks }\end{array}$ & 2 & 3.3 & 20 & 32.9 & 39 & 63.9 & 4 \\
\hline 6 & $\begin{array}{l}\text { I provide feedback for any assessment task } \\
\text { within two days. }\end{array}$ & 3 & 4.9 & 16 & 26.2 & 39 & 63.9 & 3.8 \\
\hline 7 & $\begin{array}{l}\text { I encourage my students to talk and share ideas } \\
\text { on the assessment task }\end{array}$ & 3 & 4.9 & 3 & 4.9 & 55 & 90.2 & 4.2 \\
\hline 8 & $\begin{array}{l}\text { I give students immediate feedback when they } \\
\text { need directions to proceed }\end{array}$ & 4 & 6.6 & 2 & 3.3 & 55 & 90.2 & 4.4 \\
\hline 9 & $\begin{array}{l}\text { I use the assessment criteria to provide learner } \\
\text { feedback on any assessment task }\end{array}$ & 2 & 3.3 & 6 & 9.8 & 53 & 86.8 & 4.2 \\
\hline 10 & $\begin{array}{l}\text { I create opportunities during lesson to review } \\
\text { learners' work and provide feedback accordingly }\end{array}$ & 0 & 0 & 2 & 3.3 & 59 & 96.7 & 4.5 \\
\hline 11 & $\begin{array}{l}\text { I provide learners with opportunities to reflect on } \\
\text { their own progress }\end{array}$ & 1 & 1.6 & 16 & 26.2 & 33 & 70.5 & 4 \\
\hline 12 & $\begin{array}{l}\text { I create opportunities for learners to act on } \\
\text { feedback provided }\end{array}$ & 0 & 0 & 9 & 14.8 & 51 & 83.6 & 4.1 \\
\hline 13 & $\begin{array}{l}\text { I provide descriptive feedback to my students } \\
\text { without marks }\end{array}$ & 32 & 52.4 & 15 & 24.6 & 14 & 22.9 & 2.4 \\
\hline 14 & $\begin{array}{l}\text { I provide written feedback comments along with } \\
\text { marks for any task }\end{array}$ & 17 & 27.9 & 13 & 21.3 & 31 & 50.8 & 3.3 \\
\hline
\end{tabular}

Almost all teachers (98.4\% and 96.7\%) use words such as "excellent", "very good" etc... as a form of feedback to encourage students and provide marks along with correct answers respectively. The document review also verified this (Figure 1 below). The sample students' exercise book showed that most teachers scored, put marks and general judgmental comments such as 'good', 'very good' etc... and correct answers if they missed it on their homework and classwork exercises.

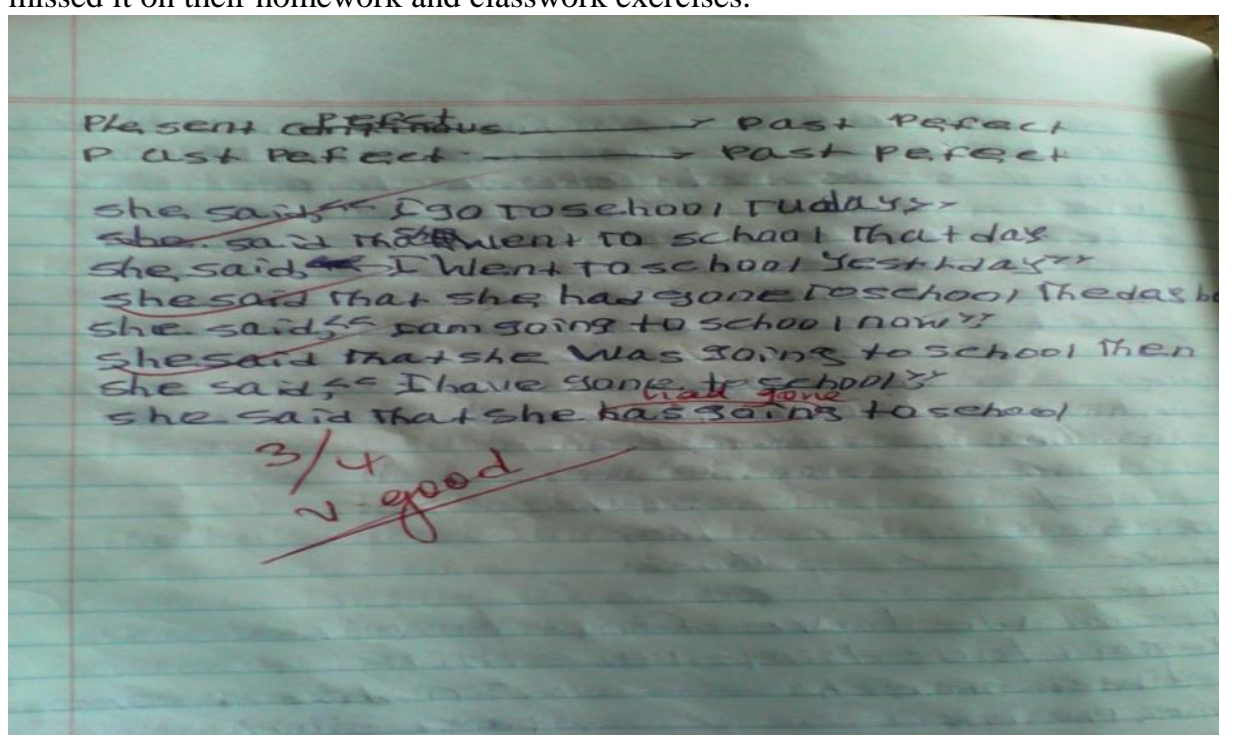

Figure 1

Students commented exercise book 
However, such types of feedbacks are judgmental which have less value to identify gaps in students' understanding and as a result to improve learning. In addition, 52.4\% and $27.9 \%$ of teachers described as they hardly provide descriptive feedback without marks and written feedback or comments along with marks for their students work respectively. From the students exercise book it is also observed that teachers give right $(\sqrt{ })$ and " $X$ " mark for the student's response and finally, after putting the total score, they indicated a general evaluation or judgment (Figure 1 above).

On the other hand, $96.7 \%$ of teachers create opportunities during the lesson to review learners' work and provide feedback accordingly, 70.5\% of them provide learners with opportunities to reflect on their own progress and $83.6 \%$ of them create opportunities for learners to act on feedback provided on a regular basis. Similarly, $90.2 \%$ of teachers give students immediate feedback when they need directions to proceed and encourage them to talk and share ideas in any assessment tasks.

In relation to the above quantitative information, an interviewee (teacher) from private primary school noted that:

I give chance for my students to work again the questions that they have missed in assignments after providing feedback for their mistakes and I checked it again whether the students have corrected it or not.

Another interviewee (teacher) on the same issue from government primary school indicated that:

I couldn't give chance for my students to rework the task they have given after comments because the number of students is very large and the students have no willingness to do the task again.

A large number of teachers also indicated that, their daily lesson plan regularly includes feedback as a main component and opportunities for learners to reflect on feedback and time to provide feedback to learners. However, results from document review showed that even if the teachers in their lesson plan include the fundamental components, how to provide feedback is not treated very well. But teachers put different evaluation mechanisms to check the attainment of the objectives what they have formulated in their lesson plan.

Table 3

One sample t-test

\begin{tabular}{lllllll}
\hline Participants & Variable & Expected Mean & Observed mean & Std. & t-value & Sig \\
\hline Teacher & PPFL & 39 & 50.56 & 4.87 & 81.02 & $.000^{*}$ \\
\cline { 2 - 7 }$(\mathrm{N}=61)$ & PP & 51 & 68.2 & 7.05 & 75.51 & $.000^{*}$ \\
\hline
\end{tabular}

Note: $\boldsymbol{P P F L}=$ Perception on the power of feedback on learning;

$$
\boldsymbol{P P}=\text { Perceived practice }
$$

The computed one-sample t-test revealed that there is a significant difference between the excepted and observed mean of teachers' perception and practice of feedback. Thus, from the result, we can conclude that teachers have a positive perception on the power of their feedback to improve students' learning. Moreover, teachers provide immediate and useful feedback for their students regularly to improve their learning. 
However, the qualitative result (data obtained from document review) indicated that, most of the feedback given for students are in the form of marks and correct answers, and include words such as "excellent", "good" etc. which have little value to show learning gaps and strategies for future learning.

There is a difference between quantitative and qualitative data. This happens because of awareness problem. Most interviewed teachers did not identify the difference between constructive feedback and judgmental feedback. Most teachers in the selected school considered returning back of exam sheets and assignments with total marks and correct answers as an effective way of feedback. However, such type of feedback is not effective to improve students' learning. Constructive feedback shows gaps in understanding and suggests ways to fill that gap in future by themselves.

Table 4

Pearson Product-Moment Correlation between teachers' perception and practice of feedback

\begin{tabular}{llll}
\hline & & Teachers' Perception & Sig \\
\hline Teachers' practice & Correlation $(\mathrm{r})$ & 0.242 & 0.061 \\
& $\mathrm{~N}$ & 61 & \\
\hline $\mathrm{P}>0.05$ & &
\end{tabular}

As indicated in Table 4, teachers' perception on the power of feedback has no significant relationship with their practice of feedback in the classroom. This happens because teachers lack appropriate knowledge and awareness about the nature, content, and purpose of feedback in the teaching-learning process.

\section{DISCUSSION}

Feedback is a vital component of formative assessment or assessment for learning to empower students to become self-regulated learners. It is by obtaining and using feedback that students are able to know both what they have done well compared to the learning objectives and how to continue to improve their learning in future. Thus, in this section, the results of this study were discussed in relation to different theories and past research shreds of evidence in the area.

\section{Teachers' Practice of Feedback in the Classroom}

Results from this study indicated that almost all teachers in second cycle primary schools provide immediate feedback to their students. However, when we see the contents and the forms of feedback from students' exercises book, it is far from what current assessment theorist emphasis on. Teachers in the selected schools mostly use feedback to give marks and correct answers on assessment tasks and to praise students. Such high usage of feedback to praise students is consistent with the work of Orsmond and Merry (2011). However, such forms of feedbacks are judgmental which have less value to identify gaps in students' understanding and as a result to improve learning. Research evidence showed that feedback in the form of marks and judgmental words undermine the self-esteem, confidence, and motivation of low achieving students rather than improve their learning (Black and Wiliam, 1998; Brookhart, 2008; Hattie \& 
Timperley, 2007). For them, feedback to improve learning should give students information about their performance in relation to specific and clear goals and helps them to identify the causes of the gap between the desired and the actual level they are and act to fill that gap. The work of Lee (2008) indicated that if teachers are aiming to improve students' learning, it is important to separate comments from grades or marks. When a student is given a mark it focuses on their performance compared to other individuals rather than on their learning and can demotivate. Moreover, feedback which focuses on grades and marks seems to affect students' belief about the role of feedback in their learning (Price, Handley, Millar \& O'Donovan, 2010).

A research conducted on assessment for learning by Black \& Wiliam, (1998) indicated that feedback is more effective when it (i) focuses on specific tasks and suggests how students can improve their performance; (ii) the suggestions for improvement should act as 'scaffolding' and helps students to think; (iii) suggests only what is necessary for students to answer by themselves; and (iv) focuses on process than on product.

\section{Teachers' Perception Regarding the Power of Feedback in Students' Learning}

The quantitative result in this study indicated that most teachers in the selected school highly perceived the power of their feedback to improve students' learning and to build students' self-esteem and confidence. On the other hand, the qualitative data revealed that teachers mostly focus on providing marks and correct answers and praising students. Similarly, a reasonable number of teachers believe in the value of feedback for social and managerial functions as opposed to learning function. This result is supported by the work of Moss and Brookhart (2009) which indicates teachers' two common misconceptions about feedback. The misconceptions are viewing effective feedback as returning of graded or marked works and detailed correction of one's work. With this kind of feedback, however, many students are more interested in how many questions they "got right" than in understanding the reasons behind their performance and try to find next steps in their learning. Thus, effective feedback describes types of strengths and deficiencies in work and suggests strategies the student might use to take next step. Moreover, Havnes, Smith, Dysthe, and Ludvigsen, (2012) stated that feedback information is effective only when it is used to fill the gap between the current understanding and the learning objectives.

Regarding the influence of teachers' perception on the practice of their feedback, the results of this study showed that there is no significant relationship between them. It contrasts with a study conducted by Weaver, (2006). He stated that the way in which feedbacks are expressed in oral or written form, and the nature of the information, is ultimately shaped by tutors' values, beliefs, and understandings. As the finding of this study indicates teachers mostly practice feedback in the form of marks or right and wrong answers. On the other hand, they highly perceive the power of feedback to improve students' learning. This mismatch occurs due to lack of appropriate awareness, knowledge, and skill about the purpose, nature, and content or forms of feedback in the selected schools. Which is maintained by the work of Moss and Brookhart as stated above. 


\section{CONCLUSION}

Even if the perception of teachers regarding the power of feedback is positive, their practice is almost judgmental which have no value for learning purpose. The majority of teachers provide immediate and useful feedback to their students regularly to improve their learning. However, in the real practice, the feedbacks given are in the form of marks and correct answers and include words such as "excellent", "very good", "good" etc... which have little value to show learning gaps and strategies for future learning.

Most teachers luck awareness to clearly identify the difference between constructive/effective feedback and judgmental feedback. Due to this, their feedback focuses on judgmental. Teachers in the selected school considered returning back of exam sheets and assignments with total marks and correct answers as an effective way of feedback. However, such type of feedback is not effective to improve students' learning. Effective feedback shows gaps in understanding and suggests ways to fill that gap in future by themselves.

If teachers have good perception regarding the power and value of feedback in improving students learning then they practice it very well. But, a significant relationship was not observed between teachers' perception on the power of feedback with their actual practice. This happens because teachers lack appropriate knowledge and awareness about the nature, content, and purpose of feedback in the teachinglearning process. Therefore, to improve the students learning, the teacher's feedback should go beyond judgmental.

\section{RECOMMENDATION}

The results of this study indicated, as teachers hold misconception about the nature and content of effective feedback and implement as they perceive, thus, intensive trainings should be given for teachers about the nature of feedback to improve students' learning. In addition, continuous follow up and supervision should be also made to identify the gaps of actual practice of feedback in the teaching-learning process.

\section{ACKNOWLEDGEMENTS}

The authors acknowledge Debre Markos University for the financial support and teachers for providing information in the research process.

\section{REFERENCES}

ARG (Assessment Reform Group). (2002). Assessment for learning: 10 Principles [online]. Retrieved from 10 December, 2017 from http://www.qca.org.uk/libraryAssets/media/4031_afl_principles.pdf.

Babbie, E. R. (2010). The basis of social research $\left(12^{\text {th }}\right.$ ed.). Belmont, CA: Wadsworth Publishing Co.

Bennett, R.E. \& Gitomer, D. H. (2009). Transforming k-12 assessment: Integrating accountability testing, formative assessment and professional support. In Wyatt-Smith, 
C. \& Cumming J. J., Educational Assessment in the 21st Century: Connecting theory and practice (pp. 43-62). New York: Springer.

Black, P. \& Wiliam, D. (1998). Assessment and classroom learning. Assessment in Education: Principles, Policy and Practice, 5(1): 7-74.

Black, P. \& Wiliam, D. (2001). Inside the Black Box: Raising standards through classroom assessment. Retrieved 28 April, 2018 from http://weaeducation.typepad.co.uk/files/blackbox-1.pdf.

Black, P.; Harrison, C.; Lee, C.; Marshall, B. \& Wiliam, D. (2003). Assessment for learning putting it into practice. New York: Open University Press.

Brookhart, S.M. (2008). How to give effective feedback to your students. ASCD: Virginia

Creswell, J.W. (2012). Educational research: planning, conducting, and evaluating quantitative and qualitative research $\left(4^{\text {th }}\right.$ ed). Boston, MA: Pearson.

De Vos, A.S., Strydom, H., Fouche', C.B., \& Delport, C.S.L. (2011). Research at Grass Roots: For the social science and human service professions $\left(4^{\text {th }}\right.$ ed). Pretoria: Van Schailk.

Eleanore, H. (2012). Teachers' classroom feedback: still trying to get it right. Pedagogies: An International Journal, 7 (1): 1-15.

Fautley, M. \& Savage, J. (2008). Assessment for learning and teaching in secondary schools. British: Learning Matters Ltd.

Gan Z, Nang, H. \& Mu, K. (2018). Trainee teachers' experiences of classroom feedback practices and their motivation to learn, Journal of Education for Teaching, DOI: 10.1080/02607476.2018.1450956

George, D. \& Mallery, P. (2003). SPSS for windows step by step: a simple guide and reference 11.0 update $\left(4^{\text {th }} \mathrm{ed}\right)$. Boston, MA: Allyn \& Bacon.

Gul, R. B.;Tharani, A. J.; Lakhani, A.; Rizvi N. F. \& Ali, S. K. (2016).Teachers' perceptions and practices of written feedback in higher education. World Journal of Education, 6 (3), 10- 20.

Harlen, W. (2006). Assessment for learning and assessment of learning. In: Harlen, W. (Ed) ASE Guide to Primary Science. Hatfield: Association for Science Education.

Hattie, J., \& Timperley, H. (2007). The power of feedback. Review of Educational Research, 77 (1), 81-112.

Havnes, A.; Smith K.; Dysthe, O. \& Ludvigsen, K. (2012). Formative assessment and feedback: Making learning visible. Studies in Educational Evaluation, 38, 21-27

Irons, A. (2008). Enhancing learning through formative assessment and feedback. New York: Routledge. 
Lee, I. (2008). Understanding teachers' written feedback practices in Hong Kong secondary classrooms. Journal of Second Language Writing, 17, 69-85.

Lee, I. (2009). Ten mismatches between teachers' beliefs and written feedback practice. ELT Journal, 63(1):13-22. Retrieved 28 April, 2018 from https://0-academic-oupcom.ujlink.uj.ac.za/eltj/article/63/1/13/361365.

Lee, I. (2017). Classroom writing assessment and feedback in L2 school contexts. Singapore, Springer.

Li, J. \& De Luca, R. (2014). Review of assessment feedback. Studies in Higher Education, 39(2), 378-393.

Montgomery, J. \& Baker, W. (2007). Teacher-written feedback: Student perceptions, teacher self-assessment, and actual teacher performance. Journal of Second Language Writing, 16(2), 82-99.

Moss, C. M. \& Brookhart S.M. (2009). Advancing formative assessment in every classroom. ASCD, Virginia.

Orsmond, P. \& Merry, S. (2011). Feedback alignment: effective and ineffective links between tutors' and students' understanding of coursework feedback. Assessment \& Evaluation in Higher Education, 36(2), 125-136.

Poulos, A., \& Mahony, M.J., (2008). Effectiveness of feedback: the students' perspective. Assessment \& Evaluation in Higher Education, 33(2):143-154.

Price, M.; Handley K., Millar, J. \& O'Donovan, B. (2010). Feedback: all that effort, but what is the effect? Assessment \& Evaluation in Higher Education, 35(3), 277-289.

Sadler, D. R. (2010). Beyond feedback: Developing student capability in complex appraisal. Assessment \& Evaluation in Higher Education, 35(5), 535-550.

Shepard, L. A. (2000). The role of assessment in a learning culture. Educational Researcher, 29(7): 4-14.

Shute, V. J. (2008). Focus on formative feedback. Review of Educational Research, 78(1), 153-189.

Spiller, D. (2014). Assessment: Feedback to promote student learning. Retrieved 8 December, 2017 from https://www.waikato.ac.nz/_data/assets/pdf_file/0008/352871/Assessment_-Feedbackto-Promote-Student-Learning.pdf.

Weaver, M. R. (2006). Do students' value feedback? Student perceptions of tutors' written responses. Assessment \& Evaluation in Higher Education, 31(3), 379-394. 